The following article and its translation into English have been reprinted from Brock TD. (1992)

Milestones in Microbiology. Science Tech Publishers, Madison, Wisconsin, pp. 27-30, 263-265,

by copyright permission of Thomas D. Brock.

\title{
Mémoire sur la fermentation appelée lactique (Extrait par l'auteur)*
}

\section{$1857 \bullet$ Louis Pasteur}

J'ai été conduit à m'occuper de la fermentation à la suite de mes recherches sur les propriétes des alcools amyliques et sur les particularités cristallographiques fort remarquables de leurs dérivés. J'aurai l'honneur de présenter ultérieurement à l'Académie des observations qui offriront une liaison inattendue entre les phénomènes de la fermentation et le caractère de dissymétrie moléculaire propre aux substances organiques naturelles.

Les conditions matérielles de la préparation et de la production de l'acide lactique sont bien connues des chimistes. On sait qu'il suffit d'ajouter à de l'eau sucrée de la craie, qui maintient le milieu neutre, plus une matiére azotée, telle que le caséum, le gluten, les membranes animales, etc., pour que le sucre se transforme en acide lactique. Mais l'explication des phénomènes est très-obscure; on ignore tout à fait le mode d'action de la matière plastique azotée. Son poids ne change pas d'une manière sensible. Elle ne devient pas putride. Elle se modifie cependant et elle est continuellement dans un état d'altération évidente, bien qu'il serait difficile de dire en quoi il consiste.

Des recherches minutieuses n'ont pu jusqu'à présent faire découvrir dans ces opérations le développement d'êtres organisés. Les observateurs qui en ont reconnu on établi en même temps qu'ils étaient accidentels et nuisaient au phénomène.

Les faits paraissent donc très-favorables aux idées de M. Liebig. ${ }^{1}$ A ses yeux, le ferment est une substance excessivement altérable qui se dé-

\footnotetext{
* Mémoire sur la fermentation appelée lactique. (1857) Comptes rendus des séances de l'Academie des Sciences. Tome 45 , pp. 913-916.

${ }^{1}$ Il résulte des recherches historiques récentes de $M$. Chevreul, insérées au Journal de Savants, que Stahl avait déjà émis des idées analogues à celles de $\mathrm{M}$. Liebig sur les causes de la fermentation alcoolique.
}

compose et qui excite la fermentation par suite de l'altération qu'elle éprouve, elle-même, en ébranlant par communication et désassemblant le groupe moléculaire de la matière fermentascible. Là, selon M. Liebig, est la cause première de toutes les fermentations et l'origine de la plupart des maladies contagieuses. Cette opinion obtient chaque jour un nouveau crédit. On peut à cette égard consulter le Mémoire de MM. Fremy et Boutron sur la fermentation lactique, les pages qui traitent de la fermentation et des ferments dans le bel ouvrage que $M$. Herhardt a laissé en mourant, enfin le Mémoire tout récent de $\mathrm{M}$. Berthelot sur la fermentation alcoolique. Ces travaux s'accordent à rejeter l'idée d'une influence quelconque de l'organisation et de la vie dans la cause des phénomènes qui nous occupent. Je suis conduit à une manière de voir entièrement différente.

Je me propose d'établir dans la première partie de ce travail que, de même qu'il existe un ferment alcoolique, la levûre de bière, que l'on trouve partout où il y a du sucre qui se dédouble en alcool et en acide carbonique, de même il y a un ferment particulier, une levûre lactique toujours présente quand du sucre devient acide lactique, et que, si toute matière plastique azotée peut transformer le sucre en cet acide, c'est qu'elle est pour le développement de ce ferment un aliment convenable.

Il y a des cas ou l'on peut reconnaître dans les fermentations lactiques ordinaires, au dessus du dépôt de la craie et de la matière azotée, des portions d'une substance grise formant quelquefois zone à la surface du dépôt. Son examen au microscope ne permet guère de la distinguer du caséum, du gluten désagrégés, etc., de telle sorte que rien d'indique que ce soit une matière spéciale, ni qu'elle ait pris naissance pendant la fermentation. C'est elle néanmoins qui joue le prin- 
cipal rôle. Je vais tout d'abord indiquer le moyen de l'isoler, de la préparer à l'état de pureté.

J'extrais de la levûre de bière sa partie soluble en la maintenant quelque temps à la température de l'eau bouillante avec quinze à vingt fois son poids d'eau. La liqueur est filtrée avec soin. On y fait dissoudre environ $\mathbf{5 0}$ grammes de sucre par litre, on ajoute de la craie et l'on sème dans le milieu une trace de la matière grise dont $j$ 'ai parlé tout à l'heure, en la retirant d'une bonne fermentation lactique ordinaire. Dès le lendemain, il se manifeste une fermentation vive et régulière. Le liquide, parfaitement limpide à l'origine, se trouble, la craie disparaît peu à peu, en même temps qu'un dépôt s'effectue et augmente continûment et progressivement au fur et à mesure de la dissolution de la craie. En outre, on observe tous les caractères et tous les accidents bien connus de la fermentation lactique. On peut remplacer dans cette expérience l'eau de levûre par la décoction de toute matière plastique azotée, fraîche ou altérée selon les cas. Voyons maintenant les caractères de cette substance dont la production est corrélative des phénomènes compris sous la dénomination de fermentation lactique. Son aspect rappelle celui de la levûre de bière quand on l'étudie en masse et égouttée ou pressée. Au microscope, elle est formée de petits globules ou de petits articles très-courts, isolés ou en amas constituant des flocons irréguliers. Ses globules, beaucoup plus petits que ceux de la levûre de bière, sont agités vivement du mouvement brownien. Lavée à grande eau par décantation, puis délayée dans de l'eau sucrée pure, elle l'acidifie immédiatement, progressivement mais avec une grande lenteur, parce que l'acidité gêne beaucoup son action sur le sucre. Si l'on fait intervenir la craie qui maintient la neutralité du milieu, la transformation du sucre est fort accéllérée; et lors même que l'on opère sur très-peu de matière, en moins d'une heure le dégagement du gaz est manifeste et la liqueur se charge de lactate et de butyrate de chaux. Il faut très-peu de cette levûre pour transformer beaucoup de sucre. Ces fermentations doivent s'effectuer de préférence à l'abri de l'air, sans quoi elles sont gênées par des végétations ou des infusoires parasites.

La fermentation lactique est donc aussi bien que la fermentation alcoolique ordinaire un acte corrélatif de la production d'une matière azotée qui a toutes les allures d'un corps organisé mycodermique probablement très-voisin de la levûre de bière. Mais les difficultés du sujet ne sont qu'a moitié résolues. Sa complication est ex- trême. L'acide lactique est bien le produit principal de la fermentation à laquelle il a donné son nom. Il est loin d'être le seul. On le trouve constamment accompagné d'acide butyrique, d'alcool, de mannite, de matière visqueuse. La proportion de ces matières est soumise aux plus capricieuses variations. Il y a une circonstance mystérieuse relative à la mannite. Non-seulement la proportion qui s'en forme est sujette aux plus grandes variations; $M$. Berthelot vient d'établir, en outre, que si l'on remplace le sucre par la mannite dans la fermentation lactique, toutes les autres conditions demeurant sensiblement les mêmes, la mannite fermente en donnant de l'alcool, de l'acide lactique et de l'acide butyrique. Comment dès lors concevoir qu'il puisse y avoir formation de mannite dans des cas de fermentation lactique, puisque, peut-on croire, elle devrait se détruire au fur et à mesure de sa production?

Étudions avec plus de soins que nous ne l'avons fait les proprietés chimiques de la nouvelle levûre. J'ai dit que lavée à grande eau et placée dans de l'eau sucrée pure, elle acidifiait progressivement la liqueur. La transformation du sucre devient, dans ces conditions, de plus en plus pénible, à mesure que le liquide prend luimême une plus grande acidité. Or, si l'on analyse la liqueur, ce qui ne peut être accompli avec succès qu'après la saturation des acides par la craie et la destruction ultérieure du sucre en excès par la levûre de bière, on trouve dans le liquide évaporé, et en proportion variable, la mannite d'une part, de l'autre la matière visqueuse. Ainsi donc la levûre lactique lavée mise en présence du sucre le transforme en divers produits parmi lesquels il y a toujours de la mannite, mais c'est à la condition que le liquide puisse devenir promptement acide; car si l'on répète exactement la même expérience avec la précaution d'ajouter un peu de craie afin que le milieu reste constamment neutre, ni gomme, ni mannite ne prennent naissance, ou mieux ne peuvent persister, parce que, on va le voir, les conditions de leur propre transformation se trouvent réunies.

$\mathrm{J}^{\prime}$ ai rappellé tout à l'heure que $\mathrm{M}$. Berthelot avait prouvé qu'en substituant la mannite au sucre dans la fermentation lactique, cette matiere fermentait. Or il est facile de se convaincre que dans les cas nombreux de fermentation de la mannite, c'est la levûre lactique qui prend naissance et produit le phénomène. Si l'on mêle à une solution de mannite pure de la craie en poudre et de la levûre lactique fraîche et lavée, 
au bout d'une heure déjà le dégagement gazeux et la transformation chimique de la mannite commenceront. Il se forme de l'acide carbonique, de l'hydrogène, et la liqueur renferme de l'alcool, de l'acide lactique, de l'acide butyrique, tous les produits de la fermentation de la mannite.

Quant à l'acide butyrique, l'expérience prouve que la levûre lactique agit directement sur le lactate de chaux en donnant du carbonate de chaux et du butyrate de chaux. Mais l'action s'exerce d'abord sur le sucre, et tant qu'il y en a dans la liqueur, la levûre le fait fermenter de préférence à l'acide lactique.

Dans des communications très-prochaines, j'aurai l'honneur de présenter à l'Académie l'application des idées générales et des nouvelles méthodes d'expérimentation de ce travail à d'autres fermentations.

\title{
Report on the Lactic Acid Fermentation (Author's abstract)
}

\author{
Translation by Thomas D. Brock, Ph.D. \\ University of Wisconsin, Madison, Wisconsin
}

My work on the properties of the amyl alcohols and on the very remarkable crystallographic properties of their derivatives has led me to a study of the process of fermentation. Later I will have the honor to present to the Academy observations that show an unexpected relationship between fermentation and the molecular asymmetry of organic molecules found in nature.

The necessary materials for the preparation and production of lactic acid are well known to chemists. It is known that it is only necessary to take a solution of sugar and add chalk, which keeps the medium neutral, a nitrogenous material, such as casein, gluten, animal membranes, etc., in order to have the sugar transformed into lactic acid. But the explanation of this phenomenon is quite obscure, since the way in which the decomposable nitrogenous material acts is completely ignored. Its weight does not change significantly. It does not putrefy. Although it becomes modified and is continually in a marked state of change, it would be difficult to speak of what its composition is.

Careful studies up to the present time have not revealed the development of organized beings during the fermentation process. Those observers who have recognized such beings have always established at the same time that they were accidental and harmful to the fermentation process.

The facts appear therefore to be very favorable for the ideas of Mr. Liebig. In his eyes, the ferment is a substance that is highly alterable, which decomposes and in so doing induces the fermentation because of the alteration that it experiences itself, communicating this agitation to the molecular group of the fermentable material and in this way bringing about its decomposition. According to Mr. Liebig, this is the principal cause of all fermentations and the origin of the majority of contagious diseases. Each day his opinion receives more favor. ... ${ }^{1}$

I propose to establish in the first part of this work that, in the same way that there exists an alcoholic ferment, the yeast of beer, which is always found wherever sugar is decomposed into alcohol and carbon dioxide, there also exists a particular ferment, the lactic yeast, that is always present when sugar becomes converted into lactic acid. Furthermore, the decomposable nitrogenous material that is able to bring about the conversion of sugar into this acid is used as a convenient nutrient for the development of this ferment.

It is possible to observe in ordinary lactic acid fermentations, on top of the sediment of chalk and nitrogenous material, a gray substance which occurs at the surface of this deposit. Under microscopic examination it can be barely distinguished from the casein, disintegrating gluten, etc. so that nothing indicates that it may be a special material, nor that it has arisen during the fermentation. Nevertheless, it is this substance that plays the principal role in the fermentation. I will shortly reveal the method for its isolation and preparation in a state of purity.

I have extracted from beer yeast its soluble

${ }^{1}$ Ellipses denote material omitted from the original article. 